\title{
Teak genetic diversity in Ghana shows a narrow base for further breeding and a need for improved international collaboration for provenance exchange
}

\author{
Tieme H V Wanders *, a , James N Ofori ${ }^{\mathrm{b}}$, Alexander Amoako ${ }^{\mathrm{c}}$, Maarten Postuma ${ }^{\mathrm{b}}$, Cornelis A \\ M Wagemaker ${ }^{\mathrm{d}}$, Elmar M Veenendaal $^{\mathrm{b}}$ and Philippine Vergeer $^{\mathrm{b}, \mathrm{d}}$ \\ ${ }^{a}$ Form international, Hattem, The Netherlands \\ ${ }^{b}$ Plant Ecology and Nature Conservation Group, Wageningen University, Wageningen, the Netherlands \\ ${ }^{c}$ Form Ghana, Sunyani, Ghana \\ ${ }^{d}$ Department of Experimental Plant Ecology, Radboud University, Nijmegen, the Netherlands
}

\begin{abstract}
We evaluated the genetic diversity of teak (Tectona grandis L.) provenances at a newly established provenance trial with 52 provenances collected from Africa, South America and Asia in Tain II Forest Reserve in Central Ghana. This provenance trial was established to widen the genetic basis for teak establishment in West Africa. Using Genotyping by Sequencing (GBS) we analysed the genetic diversity of these provenances. Results of the study revealed that, although acquired from a wide geographical range, most teak provenances in the trial belong to only two distinct groups that are closely related. The implication of this finding is that, for breeding, a wider range of provenances is needed from the original teak distribution areas, and more specifically from Southern India. We conclude that urgent protection of older existing sources of genetic variation in teak, as well as an improvement of international collaboration under the Nagoya protocol with countries with native teak populations, is necessary.
\end{abstract}

Keywords: Teak, Tectona grandis L, provenance trial, Ghana, GBS

Citation: Wanders, T. H. V., Ofori, J. N., Amoako, A., Postuma, M., Wagemaker, C. A. M., Veenendaal, E. M., Vergeer, P. (2021). Teak genetic diversity in Ghana shows a narrow base for further breeding and a need for improved international collaboration for provenance exchange. Genetic Resources 2 (4), 44-54. doi: 10.46265/genresj.UGUD8568.

(C) Copyright 2021 the Authors.

This is an open access article distributed under the terms of the Creative Commons Attribution License (CC BY 4.0), which permits unrestricted use, distribution, and reproduction in any medium, provided the original author and source are credited.

\section{Introduction}

Teak is a high-quality timber species of great importance in plantation establishment throughout the tropics. Teak (Tectona grandis L.) is naturally distributed in Myanmar, India, Laos and Thailand (White, 1991) but can now be found in about 36 countries in Tropical Asia, South America and Africa (Koskela et al, 2014). A record area of about 5.7 million ha of teak has been planted (Bhat and Hwan, 2004; Nair, 2007), underlining the economic importance of teak for tropical forestry. Teak has reached

${ }^{*}$ Corresponding author: Tieme H V Wanders (t.wanders@forminternational.nl) such a large plantation area because it is easy to cultivate in a wide climatic amplitude (Orwa et al, 2009), grows fast and produces valuable timber. Growth rates of 15 to $20 \mathrm{~m}^{3} / \mathrm{ha} /$ year are not uncommon on good sites. (Ugalde-Arias, 2013; Jerez and Coutinho, 2017) and the value of the timber can reach up to $800 \mathrm{USD} / \mathrm{m}^{3}$ C/F (ITTO, 2020).

Except for the establishment of provenance trials in the 1970s, little effort seems to have gone into the improvement of genetic diversity in the countries where teak is widely planted. In fact, the trend seems to point to a narrowing of the genetic basis due to the wide use of the so called "Solomon Island Clones", which indeed provide superior growth and 
shape of the trees under many circumstances in various countries (Chaix et al, 2011; Goh and Monteuuis, 2012; Ugalde-Arias, 2013). Although such clones contribute to the present success and financial attractiveness of teak planting, tree planters should heed their genetic diversity. To help mitigate against the effects of climate change, the appearance of new diseases, and to allow for improvement of other qualities such as growth speed and heartwood formation, genetic diversity is key and should receive more attention (Graudal and Moestrup, 2017). It is important to initiate and support selection and testing of superior individuals in local breeding programmes because many traits such as bole straightness, proportion of heartwood and fine branching, which are important for commercial production of teak, have a genetic background (Kjær et al, 1996, 1999; Fofana et al, 2008), but the phenotypic manifestation of traits is not the same in each locality.

In Ghana, teak is the prime plantation species with well over 150,000 hectares planted since 2002 (FSDFC Ghana, 2017). At present, for the development of teak plantations in Ghana, a very limited number of seed sources are available (Wanders, 2014; FSD-FC Ghana, 2017). Most of these seed sources are 'unproven', which means that the stands have been identified as seed stands, but progeny trials are not available to support the selection of these stands for this purpose. The material from these stands is now systematically evaluated at the Tain II Forest Reserve provenance trial at Form Ghana Ltd.

The stands that are currently used as seed sources were mostly planted in the 1980s and 1990s, many of them with material from Kihuhwi in Tanzania (FSDFC Ghana, 2017). Other sources of planting material are what remains of an international teak provenance trialing effort containing 13 provenances from India, Laos, Indonesia and Ghana planted between 1972 and 1975 by the Danish Development Cooperation DANIDA and the Forest Research Institute of Ghana FORIG (Keiding et al, 1986). A clonal seed orchard has been developed based on material from this trial by FORIG at Jimira in Ghana. From these sources, plantation developers presently obtain seeds for plantation establishment. Some also resort to importation of seed from other countries.

Recognising the need for a wider genetic pool to source seeds, Form Ghana Ltd started a new provenance trial in 2015 in which, over several years, 52 accessions of teak coming from Ghana, Tanzania, Côte d'Ivoire, Malaysia, Brazil, Costa Rica, Honduras, and indirectly from India and Indonesia, were planted (Wanders, 2020).

While these provenances represent a global distribution of teak, there is great uncertainty on their genetic kinship. In this study, we investigated the genetic diversity of teak provenances presently grown for testing in Ghana. We evaluated how closely related the provenances are and whether the aim of a wider genetic base for the teak industry in West Africa can be achieved under the present conditions and with the material currently accessible.

\section{Materials and methods}

\section{Trial location}

The trial is located in block A42 in the Tain II Forest Reserve (Figure 1). The coordinates of the location are $7^{\circ} 37^{\prime} 53.78^{\prime \prime} \mathrm{N}$ and $2^{\circ} 38^{\prime} 26.31^{\prime \prime} \mathrm{W}$. The layout of the trial is a block design with blocks of 49 trees per provenance. For most provenances there is at least one replicate, but some have several replicates. Planting started in 2015 and new material has been added annually, while also adding already present material to make comparisons within and between the years possible. In 2020 the trial covered 12 hectares.

\section{Genetic sampling and sample library preparation}

Leaf samples (one sample per provenance) were collected at Form Ghana's Tain II provenance trial and at Form Ghana's nursery in May 2019. Leaf samples were immediately dried with silica gel and stored for further processing. A total of 41 trees of 37 different accessions were sampled.

Genomic DNA extraction was done using a Nucleospin 96 Plant II Kit from Bioké, following the manufacturer's instructions. Genetic variation was measured using Genotyping by Sequencing (GBS) (Elshire et al, 2011). First, 88 to $278 \mathrm{ng}$ of genomic DNA (gDNA) of each of 41 samples was digested by two restriction enzymes (AseI and NsiI) after which, two indexed adapters were ligated to the DNA fragments. The main change in the adapter design was the incorporation of three random Unique Molecule Identifier (UMI) nucleotides per adapter for the identification of PCR duplicates within each amplified GBS library. After ligation, individual samples were cleaned by two subsequent Nucleo-Mag (Macherey-Nagel, Germany) cleanup steps of $1 \mathrm{x}$ and $0.8 \mathrm{x}$ beads. A small volume test PCR (15 cycles) was performed using KAPA HiFi HotStart readyMix (Roche Diagnostics, Switzerland). The resulting product was diluted $10,000 \mathrm{x}$ prior to qPCR quantification (KAPA Library Quantification Kit for HTS, Roche Diagnostics, Switzerland). The result of the qPCR was subsequently used to equimolarly pool the original cleaned digestion/ligation products. This pooled product was concentrated using a column-based NucleoMag PCR clean-up (Macherey-Nagel, Germany) and nick repaired using DNA polymerase I (50 $\mu \mathrm{L}$ reaction). The nick repaired product was amplified in five reactions of $10 \mu \mathrm{L}$ each and cleaned by two subsequent NucleoMag (Macherey-Nagel, Germany) clean-up steps using $1 \mathrm{x}$ and $0.8 \mathrm{x}$ beads, respectively. The average library size was 1,177 bp. The final GBS library was quantified by qPCR, pooled with other libraries and spiked with 10\% PhiX prior to sequencing. This increases the DNA complexity of the library in order to improve the Hiseq colour matrix estimation for which the first 11 sequencing cycles are 


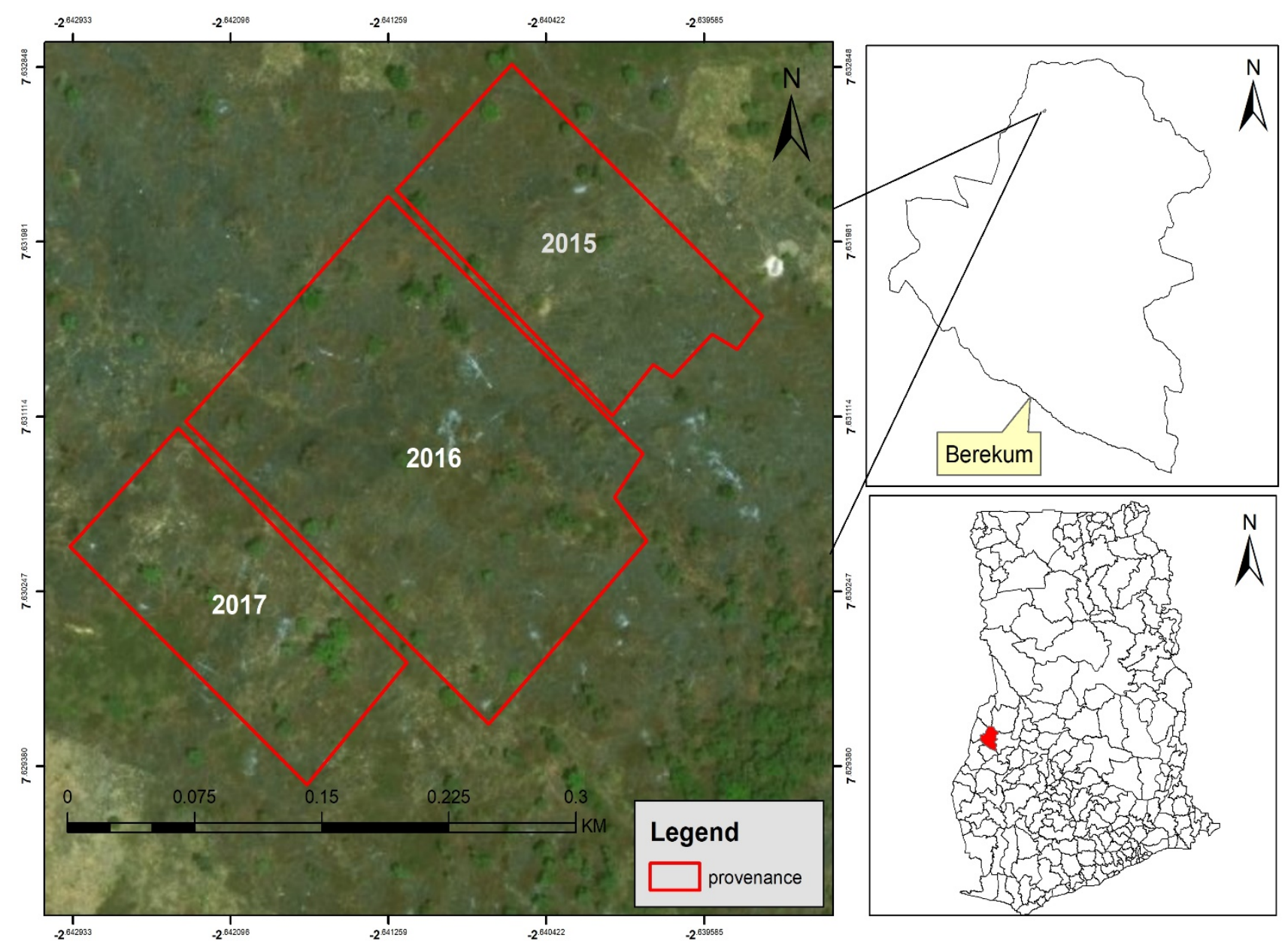

Figure 1. Map showing the location of the provenance trial in Ghana, and the various planting years sampled.

used overlapping with our index region. Sequencing was performed by Novogene (Hong Kong) on an Illumina Hiseq X-Ten sequencer, producing 2x150bp Paired-End (PE) sequencing reads. In total 0.4 sequence lane was devoted to the 41 teak GBS libraries, providing a total of $232,995,422$ raw reads.

\section{Data analysis}

Demultiplexing, de novo reference construction, mapping and SNP calling of the DNA sequences were conducted using Stacks version 2.4 (Catchen et al, 2013). PCR duplicates were removed using clone filter based on the UMI nucleotides, followed by demultiplexing using process radtags. To identify SNPs from the reads we used the "denovo_map.pl" script using -m 3 -M 5 -n 5 based on exploratory runs using a range of values (m 2-6, -M 3-7 and $n=M$ ) to maximise the quality of SNPs for this dataset (Paris et al, 2017). After mapping, data was filtered using VCF tools (Danecek et al, 2011). The applied filter first removed all loci which were not present in more than $50 \%$ of individuals, had a genotype quality below 30 or had a mean depth lower than six. After this, individuals with more than $80 \%$ missing data were removed. All SNPs, which were not present in all individuals and had an individual sample depth less than 10, were removed. Four duplicate datasets were removed from the analysis, resulting in a total of 37 samples. We used STRUCTURE (Pritchard et al, 2000) on 1000 randomly selected SNPs to assess patterns of genetic structure in the samples, with a number of assumed populations (K) of $1-7$, with 10 replicates per K. We used 1,000,000 burn-in and 500,000 reps. Afterwards, the output data was analysed using structure selector (Li and Liu, 2018). Clustering was done using the Adgenet package (Jombart and Ahmed, 2011) in R version 3.5.3 (R Core Team, 2019). Genetic distance was calculated using the R-package Adegenet, using dist(method="Euclidian"). Principal component analysis was done with the function dudi.pca from the Rpackage Ade4. All scripts used in this analysis are available at https://github.com/MaartenPostuma/Teak-anal ysis. Demultiplexed reads are available under BioProject PRJNA756980 at NCBI (https://www.ncbi.nlm.nih.gov /bioproject/PRJNA756980). 
Table 1. Analysed provenances, ID and their origin in this study.

\begin{tabular}{|c|c|c|c|c|c|}
\hline $\begin{array}{l}\text { Sample } \\
\text { no. }\end{array}$ & $\begin{array}{l}\text { ID / } \\
\text { Provenance }\end{array}$ & Country & Country & $\begin{array}{l}\text { Expected } \\
\text { origin }\end{array}$ & $\begin{array}{l}\text { Literature describing the } \\
\text { source }\end{array}$ \\
\hline 1 & Brazil 700 & Brazil & $\begin{array}{l}\text { Imported clones } \\
\text { through Proteca }\end{array}$ & $\begin{array}{l}\text { Solomon } \\
\text { Islands }\end{array}$ & \multirow{2}{*}{$\begin{array}{l}\text { (Goh and Monteuuis, } \\
\text { 2009; Monteuuis and Goh, } \\
\text { 2015) }\end{array}$} \\
\hline 2 & Brazil 701 & Brazil & $\begin{array}{l}\text { Imported clones } \\
\text { through Proteca }\end{array}$ & $\begin{array}{l}\text { Solomon } \\
\text { Islands }\end{array}$ & \\
\hline 3 & Bouaké (64) & Côte d'Ivoire & Bouaké & Côte d'Ivoire & (Wanders (2014) \\
\hline 4 & Bamoro & Côte d'Ivoire & $\begin{array}{l}\text { Bamoro seed stand } \\
\text { SODEFOR }\end{array}$ & Côte d'Ivoire & $\begin{array}{l}\text { (Dupuy and Verhaegen, } \\
\text { 1993; Kadio, 2006; Kokou, } \\
\text { 2010) }\end{array}$ \\
\hline 5 & Bangsri Pati & Ghana & $\begin{array}{l}\text { Danida provenance } \\
\text { Trial in Nsoatre }\end{array}$ & Indonesia & \multirow[t]{3}{*}{$\begin{array}{l}\text { (Keiding et al, 1986; Kjær } \\
\text { et al, 1995) }\end{array}$} \\
\hline 6 & Brazil T & Brazil & Mato Grosso & Brazil & \\
\hline 8 & Catie & Costa Rica & 278 Peñas Blancas & Costa Rica & \\
\hline 9 & Dunkwa & Ghana & $\begin{array}{l}\text { Oppon Mansi forest } \\
\text { reserve }\end{array}$ & Tanzania & \multirow[t]{2}{*}{ (Wanders, 2014) } \\
\hline 10 & Brazil F & Brazil & Mato Grosso & Brazil & \\
\hline 11 & Goaso & Ghana & $\begin{array}{l}\text { Bia Tano forest } \\
\text { reserve }\end{array}$ & Tanzania & \multirow[t]{2}{*}{ (Wanders, 2014) } \\
\hline 12 & Honduras & Honduras & $\begin{array}{l}\text { La Cumbre seed } \\
\text { stand }\end{array}$ & Honduras & \\
\hline 13 & Jimira & Ghana & Jimira forest reserve & $\begin{array}{l}\text { Mixed from } \\
\text { Nsoatre PT in } \\
\text { Ghana }\end{array}$ & (Wanders, 2014) \\
\hline 14 & Kihuhwi p68 & Tanzania & $\begin{array}{l}\text { Provenance trial in } \\
\text { Longuza }\end{array}$ & Tanzania & \multirow[t]{4}{*}{$\begin{array}{l}\text { (Madoffe and Maghembe, } \\
\text { 1988) }\end{array}$} \\
\hline 15 & Kihuwi & Tanzania & $\begin{array}{l}\text { Kihuhwi forest } \\
\text { reserve }\end{array}$ & Tanzania & \\
\hline 16 & Kiroka & Tanzania & Kiroka seed stand & Tanzania & \\
\hline 17 & KVTC & Tanzania & $\begin{array}{l}\text { Imported from KVTC } \\
\text { seed stand }\end{array}$ & Tanzania & \\
\hline 18 & La Téné & Côte d'Ivoire & $\begin{array}{l}\text { La Téné seed stand, } \\
\text { SODEFOR }\end{array}$ & $\begin{array}{l}\text { Côte d'Ivoire } \\
\text { (but based on } \\
\text { PT, many } \\
\text { provenances } \\
\text { possible) }\end{array}$ & $\begin{array}{l}\text { (Dupuy and Verhaegen, } \\
\text { 1993; Kadio, 2006; Kokou, } \\
\text { 2010) }\end{array}$ \\
\hline 19 & Longuza & Tanzania & Imported from SFI & Tanzania & $\begin{array}{l}\text { (Madoffe and Maghembe, } \\
\text { 1988) }\end{array}$ \\
\hline 20 & Luasong & Malaysia & $\begin{array}{l}\text { Luasong, Tawau, } \\
\text { Sabah }\end{array}$ & Malaysia & $\begin{array}{l}\text { Goh and Monteuuis } \\
\text { (2009); Monteuuis and } \\
\text { Goh (2015) }\end{array}$ \\
\hline 21 & Miro 1 & Costa Rica & Catie 194/166- 25 & Costa Rica & \\
\hline 22 & Miro 2 & Costa Rica & Catie 212/09B- 11 & Costa Rica & \multirow{5}{*}{$\begin{array}{l}\text { (Madoffe and Maghembe, } \\
\text { 1988) }\end{array}$} \\
\hline 23 & Miro 3 & Costa Rica & Catie 221/45C- 12 & Costa Rica & \\
\hline 24 & Mtibwa p61 & Tanzania & $\begin{array}{l}\text { Provenance trial in } \\
\text { Longuza }\end{array}$ & Tanzania & \\
\hline 25 & Mtibwa & Tanzania & Mtibwa seed stand & Tanzania & \\
\hline 26 & Nigeria p67 & Tanzania & $\begin{array}{l}\text { Provenance trial in } \\
\text { Longuza }\end{array}$ & Tanzania & \\
\hline
\end{tabular}




\begin{tabular}{|c|c|c|c|c|c|}
\hline \multicolumn{6}{|c|}{ Table 1 continued } \\
\hline $\begin{array}{l}\text { Sample } \\
\text { no. }\end{array}$ & $\begin{array}{l}\text { ID / } \\
\text { Provenance }\end{array}$ & Country & Country & $\begin{array}{l}\text { Expected } \\
\text { origin }\end{array}$ & $\begin{array}{l}\text { Literature describing the } \\
\text { source }\end{array}$ \\
\hline 27 & Nilambur & Ghana & $\begin{array}{l}\text { Danida provenance } \\
\text { trial in Nsoatre }\end{array}$ & Kerala, India & $\begin{array}{l}\text { (Keiding et al, 1986; Kjær } \\
\text { et al, 1995) }\end{array}$ \\
\hline 28 & North India & North India & North India & North India & \\
\hline 29 & Oumé & Côte d'Ivoire & Oumé & Côte d'Ivoire & \\
\hline 30 & Pampawie & Ghana & $\begin{array}{l}\text { Pampawie Forest } \\
\text { Reserve }\end{array}$ & Ghana & (Wanders, 2014) \\
\hline 31 & Perlis & Malaysia & $\begin{array}{l}\text { Perlis seed stand, } \\
\text { Taliwas, Lahad Datu, } \\
\text { Sabah }\end{array}$ & Malaysia & $\begin{array}{l}\text { (Goh and Monteuuis, } \\
\text { 2009; Monteuuis and Goh, } \\
\text { 2015) }\end{array}$ \\
\hline 32 & Sangoué & Côte d'Ivoire & $\begin{array}{l}\text { Sangoué seed stand, } \\
\text { SODEFOR }\end{array}$ & Côte d'Ivoire & $\begin{array}{l}\text { (Dupuy and Verhaegen, } \\
\text { 1993; Kadio, 2006; Kokou, } \\
\text { 2010) }\end{array}$ \\
\hline 33 & $\mathrm{~T} 1$ & Ghana & $\begin{array}{l}\text { Danida provenance } \\
\text { trial in Nsoatre }\end{array}$ & $\begin{array}{l}\text { not traceable } \\
\text { (likely } \\
\text { Nilambur) }\end{array}$ & $\begin{array}{l}\text { (Keiding et al, 1986; Kjær } \\
\text { et al, 1995) }\end{array}$ \\
\hline 34 & $\mathrm{~T} 4$ & Ghana & $\begin{array}{l}\text { Danida provenance } \\
\text { trial in Nsoatre }\end{array}$ & $\begin{array}{l}\text { not traceable } \\
\text { (likely Bangsri } \\
\text { Pati) }\end{array}$ & $\begin{array}{l}\text { (Keiding et al, 1986; Kjær } \\
\text { et al, 1995) }\end{array}$ \\
\hline 35 & Taliwas & Malaysia & $\begin{array}{l}\text { Taliwas, Lahad Datu, } \\
\text { Sabah }\end{array}$ & Malaysia & $\begin{array}{l}\text { (Goh and Monteuuis, } \\
\text { 2009; Chaix et al, 2011; } \\
\text { Monteuuis and Goh, 2015) }\end{array}$ \\
\hline 36 & Temandsang & Ghana & $\begin{array}{l}\text { Danida provenance } \\
\text { trial in Nsoatre }\end{array}$ & Indonesia & $\begin{array}{l}\text { (Keiding et al, 1986; Kjær } \\
\text { et al, 1995) }\end{array}$ \\
\hline 37 & Topslip & Ghana & $\begin{array}{l}\text { Provenance trial in } \\
\text { Longuza }\end{array}$ & $\begin{array}{l}\text { Coïmbatore, } \\
\text { India }\end{array}$ & $\begin{array}{l}\text { (Madoffe and Maghembe, } \\
\text { 1988) }\end{array}$ \\
\hline 38 & Worawora & Ghana & $\begin{array}{l}\text { Wora Wora forest } \\
\text { reserve }\end{array}$ & Ghana & (Wanders, 2014) \\
\hline
\end{tabular}




\section{Results}

A total of 23,182 SNPs were obtained after filtering, which ensured the accuracy and reliability of subsequent genetic diversity and population structure analyses. The optimal value of $\mathrm{K}$ was determined by Evanno's delta $\mathrm{K}$ method (Evanno et al, 2005). Two clearly defined main clusters $(\mathrm{K}=2$; Figure 2) and a maximum of 4 clusters $(\mathrm{K}=4$; Figure 2$)$ were revealed. The most likely number of clusters was $\mathrm{K}=2$. These two main clusters are at a great genetic distance from each other and are clustered primarily according to geographical region: one cluster consisted of teak stands originating from Asia and the Pacific and the other cluster originating from South America and Africa. In addition, $\mathrm{K}=3$ and $\mathrm{K}=4$ showed some variation within the two main clusters. When $\mathrm{K}=3$, accessions originating from Côte d'Ivoire and Malaysia for example could be distinguished and at $\mathrm{K}=4$ accessions from the Solomon Islands separated from the other accessions from the Asia-Pacific cluster. The list of provenances, ID and their collected and expected origin (as inferred from the genetic analysis) is shown in Table 1. 'Origin of collection' in this table means how Form Ghana obtained the material and the 'expected origin' in the table refers to the origin to which the material can be traced in the literature.

Further analysis of the two main clusters clearly showed more genetic similarities within the South America-Africa cluster indicating less genetic variability as compared to the Asia-Pacific cluster, which had less genetic similarities indicating more variation in genotype especially in the Asian cluster. This was also illustrated by a principal component analysis based on genetic distance (Figure 3) and the number of polymorphic sites (SNPs) within the two clusters. In the Asia-Pacific cluster, $94 \%$ of SNPs were polymorhpic compared to $74 \%$ of polymorphic SNPs in the South America-Africa cluster, even though the latter had more individuals. In addition, only 1364 private alleles were found in the South America-Africa cluster as compared to 6201 private alleles in the Asia-Pacific cluster. Mean Euclidean-based genetic distance was calculated as $87.25 \pm 19.35$ within the South America-Africa cluster (green + pink), $117.19 \pm 43.9$ within the Asia-Pacific cluster (yellow + red), and $161.35 \pm 32.35$ between these two main clusters (Figure 2). These data showed substiantally higher levels of genetic variation in the Asia-Pacific cluster and suggest low levels of genetic variation in the South America-Africa cluster.

\section{Discussion}

The results in Figure 2 show two main clusters of genetic variation for the 37 teak provenances sampled in the Tain II Forest Reserve. The first cluster mainly consists of teak stands from Africa and South America and the second of provenances from Asia and the Pacific. Data on the number of polymorphic sites in the two clusters and genetic distance within and between the clusters indicate less genetic variation between provenances in the Africa-South America cluster and a high genetic variation between provenances within the Asia-Pacific cluster and especially in the Asia cluster.

Grouping the material shows that material from Indonesia and Africa is closely related which confirms the conclusions of Verhaegen et al (2010) that teak from Ghana and Indonesia could be originating from Laos while teak from other African places can be traced back to North India (Fofana et al, 2008). Together, they form a group that is different from the Thai and South India provenance groups. In this study we can now add the South American provenances to the latter group. The attribution of the Indonesian provenances to Laos was also found by Hansen et al (2017), who unfortunately did not sample from Ghana. The grouping of material from Malaysia and India in one group can be explained by the collection of Indian provenances in provenance trials in Côte d'Ivoire for the establishment of the Malaysian plots (Goh and Monteuuis, 2009). The link between the material from the Solomon Islands and India should not be surprising as the Solomon Islands have no indigenous teak population and their population was built up from foreign material which mostly came from India (Raomae, 2012).

Most teak provenances within the Africa-South America cluster showed less genetic variation in this study which confirms that African teak provenances most likely originate from a limited range in North India and none of the African provenances are from South India (Verhaegen et al, 2010).

Some uncertainty on the exact origin of provenances in our study remains. Attribution to a certain origin as indicated by the structure analysis was based on the genetic relatedness of samples from single trees representing each provenance. Based on this, provenances that were genetically more related were then assigned to the same cluster. However, some provenances originated from mixed clonal seed orchards (Jimira, Kiroka, Sangoué and La Téné) as presented in Table 1. The seed obtained from such seed orchards is potentially more diverse and sampling may have covered only part of the locally present diversity. As a consequence, more sampling in the same population of seedlings from such orchards could potentially also identify genetic material from the other cluster.

Despite the uncertainty of the origin of some provenances, the results show that although imports were made from very different areas in the tropics, the achieved gain in genetic diversity is very limited and reflects that, over time, teak provenances from a limited number of sources have spread over a wide area (Fofana et al, 2008). This also means that at present, new imports of teak seeds into e.g. Ghana, mostly do not constitute a new genetic accession added to the gene pool. Before going through the process of obtaining permits and importing seeds from a presumed new accession, it is important to compare its genetic makeup with the existing provenances. It is also important to further investigate the current collection of provenances 


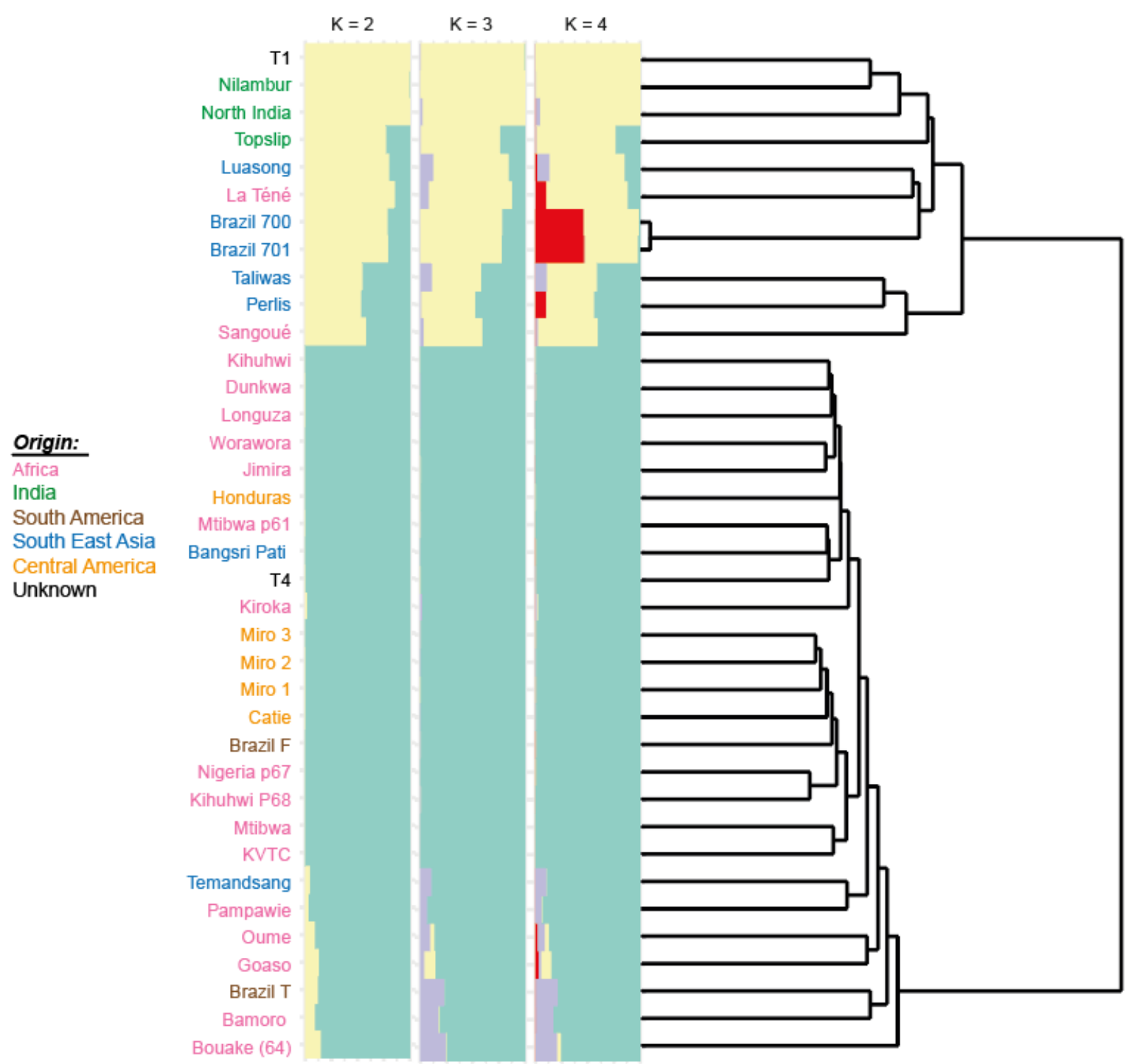

Figure 2. Clustering of teak stands of different provenances. Shown is a dendrogram based on genetic distance (right part) and the different clusters as identified by the structure analysis (green, cluster 1; yellow, cluster 2; pink, cluster 3 and red, cluster 4). The dendrogram was generated by hierarchical clustering (UPGMA) based on genetic dissimilarity. Vertical lines in the dendrogram give the amount of genetic dissimilarity and represent genetic lineages. Each row represents an individual tree per provenance, with the length of the different colour segments representing the proportion of a cluster in an individual's genetic makeup. $\mathrm{K}=2-4$ indicates the number of genetic clusters that were revealed in this structure analysis from 2 to 4 . The most likely number of clusters was $\mathrm{K}=2$.

so that the search for additional genetic material for teak provenance pools in West Africa can be conducted with more focus.

Our findings emphasise the need for acquiring teak provenances from areas of its original distribution that are high in genetic diversity and are not in the present provenance trial, one such area being South-West India (Hansen et al, 2017) and the semi-moist east coast of India (Hansen et al, 2015). The analysis of Vaishnav and Ansari (2018) indicates that genetic resources in India may be a source for screening resilient superior provenances for improvement strategies for sustainable production of quality timber on a large scale. Various examples exist for the benefit of matching specific provenances to specific local conditions. Indigenous teak populations from Annamalai Hills in the Indian states of Kerala and Tamil Nadu contain well performing provenances for Tanzania (Madoffe and Maghembe, 1988; Pedersen et al, 2007), while a Nilambur provenance from India and a Savannahket provenance from Laos have been assessed as very suitable for Ghana (Adu-Bredu et al, 2019).

Currently it is difficult to obtain accessions from some of the countries containing the high diversity areas, as they have banned the export of seeds and sometimes also of clones of their genetic heritage. 


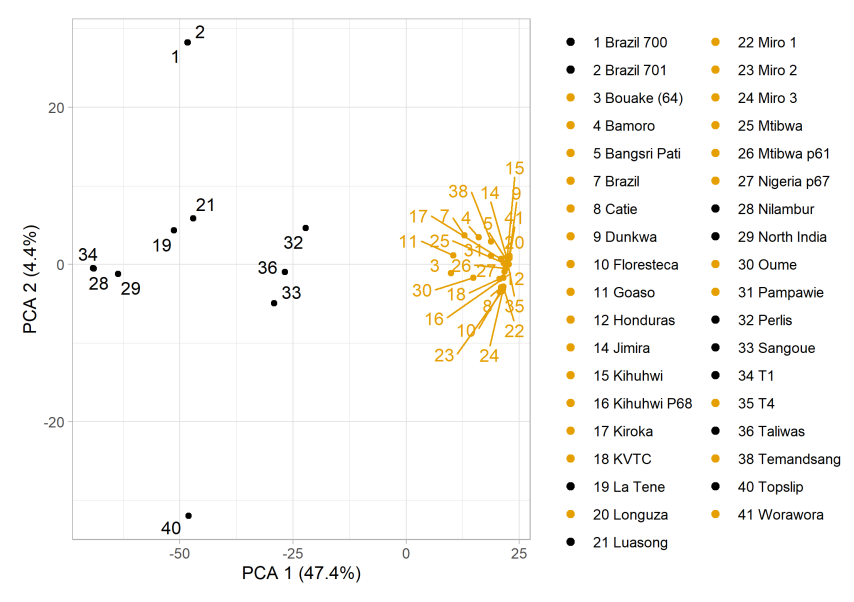

Figure 3. Principal components analysis on genetic distance of the different teak accessions. The different accessions are indicated by numbers, the two main clusters as identified by structure analysis by different colours.

It is, for instance, impossible to import seeds from India (Government Of India , 2002). This makes it all the more urgent to get a full view of the genetic make-up of trees planted in old (pre-Nagoya protocol) provenance trials such as the series of international provenance trials planted in the 1970s (Keiding et al, 1986). More and more of these trials are lost to felling, e.g. recently Longuza provenance trial in Tanzania (Wanders, personal observation) and to disaster as is the case of St. Croix in Puerto Rico, which was part of the series of international provenance trials set up by DANIDA and was destroyed by hurricanes (Morgan, personal communication, 2016). The original series of international provenance trials by DANIDA contained 75 provenances which were under test on over 50 locations, with 41 original teak provenances originating from the natural range of teak (Keiding et al, 1986). These trials potentially remain a very important source of genetic variety for any breeding programme (Koskela et al, 2014; Adu-Bredu et al, 2019) and their conservation should be a high priority. As the climate is changing and forestry is to adapt to the climate, becoming either wetter or drier, the need to access a wider range of genetic material may become more and more important in tropical forestry (Koskela et al, 2014).

At present, the Nagoya Protocol on access to genetic resources and benefit sharing (ABS) (CBD, 2011) could govern the sharing of benefits resulting from exchanges of genetic material in a more structured and mutually beneficial manner. It is not yet clear if the signing of the Nagoya protocol will make it possible to again obtain seeds from countries having interesting genetic resources, but prohibiting export of seeds and other propagation materials. Documents that need to be elaborated per seedlot, such as the Prior Informed Consent and benefit sharing agreement, create barriers that need urgent addressing at supranational level. Koskela et al (2014) provide an insight into the amount of paperwork necessary in order to plant a provenance trial, which is another argument to carefully conserve pre-Nagoya planted trials and exchange genetic material from these. The amount of work going into the drafting and signing of ABS and mutually agreed terms (MAT) may make it worthwhile to engage in only for commercially high returning crops.

In international forestry, non-profit initiatives to exchange seeds exist. One of these, CAMCORE (https:/ /camcore.cnr.ncsu.edu/) has done excellent work on the collection and distribution of seeds for broad testing of Pinus and Eucalyptus species. CAMCORE has organised expeditions for the collection of seeds of species interesting for forestry and tree breeding and distributed these seeds to be planted in trials at member organisations and companies. CAMCORE has recently also started work on teak (Hodge et al, 2019). The cost of the membership fee for this organisation, however, is not accessible to all organisations involved in plantation development. More exchange would certainly improve the possibilities of increasing the gene pool for teak breeding.

\section{Conclusion}

As our work has shown, it can be difficult to have access to diverse genetic materials. With the uncertainties about the long-term fitness of currently available genetic material under climate change and possible disease vulnerability, having access to genetic diversity is becoming increasingly important. Because not all genetic diversity has a direct commercial interest, the creation and maintenance of a national gene bank or national collection (NCCPG, 2007; FAO, 2014) should be a national priority. Conservation of teak genetics in Thailand has been described by Kaosa-Ard et al (1998) and Graudal et al (1999). In India genebanks have also been created such as the National Teak Germplasm Bank in Chandrapur (Maharashtra) whose genetic diversity has been analysed (Mahesh et al, 2016). Lack of formal protection of tree genetic resources can cause genetic material to be lost unnoticed. Through cooperation between the countries that took part in past international provenance trials on teak, each participant country could, through exchanges, build up a collection of most, if not all, accessions of teak originally distributed. This should be done in addition to addressing of international barriers for exchange of genetic material of teak from its original range mentioned earlier. A national teak genebank collection for Ghana (and other African teak producing countries) would then become an excellent centre for the distribution and conservation of genetic material. The facility managing such a collection should become a member of CAMCORE or a similar organisation to further facilitate exchange.

\section{Acknowledgements}

We would like to thank Form Ghana Ltd and, more specifically, Mr Willem Fourie, for the possibility to sample their provenance trial and for the financial 
contribution to the analysis of the findings. This study also received co-funding from Wageningen University.

\section{Author contributions}

Tieme Wanders, Philippine Vergeer, James Ofori and Elmar Veenendaal conceived and planned the experiments; James Ofori, Alexander Amoako and Tieme Wanders collected data; Philippine Vergeer, Niels Wagemaker, Maarten Postuma, James Ofori, Tieme Wanders and Elmars Veenendaal contributed to analysis and interpretation of the results; Tieme Wanders took the lead in writing the manuscript. All authors provided critical feedback and helped shape the research, analysis and manuscript.

\section{Conflict of interest statement}

The authors declare no conflicts of interest.

\section{References}

Adu-Bredu, S., Ofori, D. A., Ræbild, A., Hansen, J. K., Koffi, A., Vigneron, P., and Kjær, E. D. (2019). Trait variations in 28-year-old teak (Tectona grandis) provenance field trials in Ghana. West Africa. Southern Forests: a Journal of Forest Science 81(1), 57-68. doi: https://doi.org/10.2989/20702620.2018.1490993

Bhat, K. M. and Hwan, O. M. (2004). Teak growers unite. ITTO Tropical Forest Update, 35. url: https://www.itto.int/direct/topics/topics_pdf download/topics $i d=6670000 \&$ no $=1 \&$ disp $=$ inline.

Catchen, J., Hohenlohe, P. A., Bassham, S., Amores, A., and Cresko, W. A. (2013). Stacks: an analysis tool set for population genomics. Molecular ecology 22(11), 3124-3140. doi: https://doi.org/10.1111/mec.12354

CBD (2011). Nagoya Protocol on Access to Genetic Resources and the Fair and Equitable Sharing of Benefits Arising from their Utilisation to the convention on Biological Diversity (Montreal, Canada) url: https://www.cbd.int/abs/doc/protocol/nagoyaprotocol-en.pdf.

Chaix, G., Monteuuis, O., Garcia, C., Alloysius, D., Gidiman, J., Bacilieri, R., and Goh, D. K. S. (2011). Genetic variation in major phenotypic traits among diverse genetic origins of teak (Tectona grandis L.f.) planted in Taliwas. Annals of Forest Science 68, 1015-1026. doi: https://doi.org/10.1007/ s13595-011-0109-8

Danecek, P., Auton, A., Abecasis, G., Albers, C. A., Banks, E., Depristo, M. A., Handsaker, R. E., Lunter, G., Marth, G. T., Sherry, S. T., Mcvean, G., and Durbin, R. (2011). The variant call format and VCF tools. Bioinformatics 27(15), 2156-2158. doi: https://dx. doi.org/10.1093/bioinformatics/btr330

Dupuy, B. and Verhaegen, D. (1993). Le Teck de plantation Tectona grandis en $\mathrm{C}^{\wedge}$ ote d'Ivoire. Bois et Forêts des Tropiques 235, 9-24. url: http://bft.cirad. $\mathrm{fr} / \mathrm{cd} / \mathrm{BFT} 235$-9-24.pdf.

Elshire, R. J., Glaubitz, J. C., Sun, Q., Poland, J. A., Kawamoto, K., Buckler, E. S., and Mitchell, S. E.
(2011). A robust, simple genotyping-by-sequencing (GBS) approach for high diversity species. PloS one 6(5). doi: https://doi.org/10.1371/journal.pone. 0019379

Evanno, G., Regnaut, S., and Goudet, J. (2005). Detecting the number of clusters of individuals using the software structure: a simulation study. Molecular Ecology 14, 2611-2620. doi: https://doi. org/10.1111/j.1365-294X.2005.02553.x

FAO (2014). Genebank Standards for Plant Genetic Resources for Food and Agriculture (Rome, Italy: Food and Agriculture Organization of the United Nations). url: http://www.fao.org/3/i3704e/i3704e.pdf.

Fofana, I. J., Lidah, J., Diarrassouba, Y., N'guetta, N., Sangare, S. P., Verhaegen, A., and D (2008). Genetic structure and conservation of teak (Tectona grandis) plantations in Côte d'Ivoire, revealed by site specific recombinase (SSR). Tropical Conservation Science 1(3), 279-292. doi: https://doi.org/10.1177/ 194008290800100308

FSD-FC Ghana (2017). National Forest Plantation Development Programme 2016 Annual report. url: https://www.oldwebsite.fcghana.org/ userfiles/files/Plantation\%20Annual\%20Report/FC\% 20AnnualReport\%202016.pdf.

Goh, D. K. S. and Monteuuis, O. (2009). Status of the "YSG Biotech" program of building teak genetic resources in Sabah. Bois et Forêts des Tropiques 301, 33-49. url: https://agritrop.cirad.fr/552335/1/Goh\& MonteuuisBFT2009.pdf.

Goh, D. K. S. and Monteuuis, O. (2012). Behaviour of the "YSG Biotech TG1-8" teak clones under various site conditions: first observations. Bois et Forêts des Tropiques 311, 5-19. url: https://agritrop.cirad.fr/ 564461/1/564461.pdf.

Government Of India (2002). Export and Import Policy and Handbook of Procedures 2002-07 F.No.305/25/2002-FTT. url: https://taxguru. in/custom-duty/exim-policy-200207-handbookprocedures-20022007-amendments-notificationsrelating-eouepzethpstpsez-schemes-reg.html.

Graudal, L. O. V., Kjær, E. D., Suangtho, V., Saardavut, P., and Kaosa-Ard, A. (1999). Conservation of Genetic Resources of Teak (Tectona grandis) in Thailand. url: https://pdfs.semanticscholar.org/ 2ae1/57f7d1b76e563786ddb6a4e57779677f5e6e. pdf?_ga $=2$.

Graudal, L. O. V. and Moestrup, S. (2017). The Genetic Variation in Natural and Planted Teak Forests: Characterisation, Use and Conservation for the Future. IUFRO World Series 36, 19-29. url: https: //www.iufro.org/uploads/media/ws36.pdf.

Hansen, O. K., Changtragoon, S., Ponoy, B., Kjær, E. D., Minn, Y., Finkeldey, R., Nielsen, K. B., and Graudal, L. O. V. (2015). Genetic resources of teak (Tectona grandis Linn. f.)-strong genetic structure among natural populations. Tree Genetics \& Genomes 11(802). doi: https://doi.org/10.1007/s11295-0140802-5 
Hansen, O. K., Changtragoon, S., Ponoy, B., Lopez, J., Richard, J., and Kjær, E. D. (2017). Worldwide translocation of teak: origin of landraces and present genetic base. Tree Genetics \& Genomes 13. doi: https: //doi.org/10.1007/s11295-017-1170-8

Hodge, G. R., Lopez, J., Acosta, J. J., Woodbridge, W. C., Jump, J., Jetton, R. M., Whittier, W. A., Hillen, A., Mcgee, J. R., and Gutiérrez, E. A. (2019). 2019 Camcore Annual Report: International Tree Breeding and Gene Conservation (Raleigh, North Carolina: Camcore/North Carolina State University). url: https://camcore.cnr.ncsu.edu/files/2020/ 04/AnnReport-2019.pdf.

ITTO (2020). ITTO Tropical Timber Market (TTM) Report. Volume 24 Number 7. url: https://www.itto. int/files/user/mis/MIS_1-15_Apr2020.pdf.

Jerez, M. and Coutinho, S. (2017). Establishment and Management of Planted Teak Forests. In The Global Teak Study. Analysis, Evaluation and Future Potential of Teak Resources, ed. Kollert, W. and Kleine, M., (Vienna: IUFRO), volume 36, 49-65.

Jombart, T. and Ahmed, I. (2011). Adegenet 1.31: new tools for the analysis of genome-wide SNP data. Bioinformatics 3070-3071. doi: https://doi.org/ 10.1093/bioinformatics/btr521

Kadio, A. A. (2006). Développement du clonage du teck et creation de plantations industrielles PD 22/98 Rev 1 (F) Rapport d'Achèvement. url: https://www.itto. int/files/itto_project_db_input/2148/Competition/ pd\%2022-98-1\%20rev1(F)\%20f_Rapport\%20d\%E2\% 80\%99Achevement\%20D\%C3\%A9veloppement\% 20du\%20clonage\%20du\%20teck\%20et_f.pdf.

Kaosa-Ard, A., Suangtho, V., and Kjær, E. D. (1998). Experience from Tree Improvement of Teak (Tectona Grandis) in Thailand volume 50 of Technical Note. (Humlebæk, Denmark: Danida Forest Seed Centre). url: https://curis.ku.dk/ws/files/37387879/ TN_50_ny.pdf.

Keiding, H., Wellendorf, H., and Lauridsen, E. B. (1986). Evaluation of an International Series of Teak Provenance Trials. Research and Documentation. url: https://static-curis.ku.dk/portal/files/35116262/ Teak_evaluation_1.pdf.

Kjær, E. D., Kajornsrichon, S., and Lauridsen, E. B. (1999). Heartwood, Calcium and Silica Content in Five Provenances of Teak (Tectona grandis L.). Silvicultural Research Report 48, 1-3. url: https://www.thuenen.de/media/institute/fg/PDF/ Silvae_Genetica/1999/Vol._48_Heft_1/48_1_1.pdf.

Kjær, E. D., Lauridsen, E. B., and Wellendorf, H. (1995). Second Evaluation of an International Series of Teak Provenance Trials. Research and Documentation. url: https://static-curis.ku.dk/ portal/files/20713023/teakii.pdf.

Kjær, E. D., Siegismund, H. R., and Suangtho, V. (1996). A Multivariate Study on Genetic Variation in Teak (Tectona grandis (L.)). Silvae Genetica 45(5-6), 361368. url: https://www.thuenen.de/media/institute/
fg/PDF/Silvae_Genetica/1996/Vol._45_Heft_5-6/ 45_5-6_361.pdf.

Kokou, K. (2010). Développement du clonage du teck et création de plantations industrielles PD 22/98 Rev.1 (F) Rapport d'Evaluation à Posteriori. url: https://www.itto.int/files/itto_project_db_input/ 2148/Ex-post/44RFM-4a-PD022-98R1F-Ex-post\% 20Full\%20Report-Cote\%20dIvoire.pdf.

Koskela, J., Vinceti, B., Dvorak, W., Bush, D., Dawson, I. K., Loo, J., Kjær, E. D., Navarro, C., Padolina, C., Bordács, S., Jamnadass, R., Graudal, L., and Ramamonjisoa, L. (2014). Utilization and transfer of forest genetic resources: A global review. Forest Ecology and Management 22-34. doi: https://doi.org/ 10.1016/j.foreco.2014.07.017

Li, Y. L. and Liu, J. X. (2018). StructureSelector: A web-based software to select and visualize the optimal number of clusters using multiple methods. Molecular Ecology Resources . doi: https://doi.org/10. 1111/1755-0998.12719

Madoffe, S. S. and Maghembe, J. A. (1988). Performance of Teak (Tectona grandis L.f.) provenances seventeen years after planting at Longuza, Tanzania. Silvae Genetica 37, 5-6. url: https://www.thuenen. de/media/institute/fg/PDF/Silvae_Genetica/1988/ Vol._37_Heft_5-6/37_5-6_175.pdf.

Mahesh, S., Vaishnav, V., Kumar, P., Mohammad, N., and Ansari, S. A. (2016). Characterization and validation of teak plus trees ramets of national teak germplasm bank through microsatellites. Tropical Plant Research 3(1), 213-220. url: https://www.tropicalplantresearch.com/archives/ 2016/vol3issue1/28.pdf.

Monteuuis, O. and Goh, D. K. S. (2015). Field growth performances of teak genotypes of different ages clonally produced by rooted cuttings, in vitro microcuttings, and meristem culture. Canadian Journal of Forest Research 45, 9-14. doi: https://doi. org/10.1139/cjfr-2014-0339

Nair, K. S. (2007). Scale, markets and economics: Small-scale enterprises in a globalizing environment. Unasylva 58(228), 3-10. url: http://www.fao.org/3/ a1346e/a1346e02.pdf.

NCCPG (2007). Action plan for conservation of plants in cultivation. url: https://www.rhs.org.uk/science/pdf/ conservation-and-biodiversity/conserving-gardenplants/actionplanconservationofplants.pdf.

Orwa, C., Mutua, A., Kindt, R., Jamnadass, R., and Anthony, S. (2009). Agroforestree Database: a tree reference and selection guide version 4.0. url: https://www.worldagroforestry.org/publication/ agroforestree-database-tree-reference-and-selectionguide-version-40.

Paris, J. R., Stevens, J. R., and Catchen, J. M. (2017). Lost in parameter space: a road map for stack. Methods in Ecology and Evolution 1360-1373. doi: https://doi.org/10.1111/2041-210X.12775

Pedersen, A. P., Hansen, J. K., Mtika, J. M., and Msangi, T. H. (2007). Growth, Stem Quality and age-age 
Correlations in a Teak Provenance Trial in Tanzania. Silvae Genetica 56, 142-148. doi: https://doi.org/10. 1515/sg-2007-0022

Pritchard, J. K., Stephens, M., and Donnelly, P. (2000). Inference of population structure using multilocus genotype data. Genetics 155(2), 945-959. doi: https: //doi.org/10.1093/genetics/155.2.945

R Core Team (2019). R: A language and environment for statistical computing. url: https://www.r-project.org/.

Raomae, R. (2012). State of Forest Genetic Resources in the Solomon Islands. url: http://www.fao.org/3/ i3825e/i3825e60.pdf.

Ugalde-Arias, L. A. (2013). TEAK: new trends in silviculture, commerzialisation and wood utilisation. (Carthago, Costa Rica: International Forestry and Agroforestry).

Vaishnav, V. and Ansari, S. A. (2018). Genetic Differentiation and Adaptability of Teak (Tectona grandis L.f.) Meta-Population in India. Plant Molecular Biology Reporter 36(3), 564-575. doi: https://doi.org/ 10.1007/s11105-018-1101-3

Verhaegen, D., Fofana, I. J., Logossa, Z. A., and Ofori, D. (2010). What is the genetic origin of teak (Tectona grandis L.) introduced in Africa and in Indonesia? Tree genetics \& genomes 6(5), 717733. doi: https://doi.org/10.1007/s11295-0100286-x

Wanders, T. H. V. (2014). Potential seed stands in Ghana. Report on a visit to Forestry Commission Seed Stands . Form International, Hattem, the Netherlands. (internal report).

Wanders, T. H. V. (2020). Teak provenance trial monitoring 2020. Form International, Hattem, the Netherlands. (internal report).

White, K. J. (1991). Teak: Some aspects of research and development. RAPA publication, Bangkok, 70p. 